\title{
Change of ankle pain after total knee replacement arthroplasty
}

\author{
Heui-Chul Gwak \\ From 4th Congress of the International Foot and Ankle Biomechanics (i-FAB) Community \\ Busan, Korea. 8-11 April 2014
}

\section{Background}

We aimed to analyze the change of ankle pain by realignment of the lower extremity after total knee arthroplasty.

\section{Methods}

We performed prospective analysis and followed up 76 patients enrolled from January 2012 to December. 2013 for at least 6 months excepting the 5 patients who were lost follow-up, 71 patients (bilateral: 9, unilateral: 62, total 80 cases) were analyzed. There were 8 men, 63 women and the average age were 69.6 years old (56-79). All surgery were performed by one operator and posterior cruciate ligament stabilized knee arthroplasty was done in all cases. Subjective ankle pain was evaluated by visual analogue scale (VAS) and clinical results were evaluated by AO-FAS ankle-hindfoot scale and SF-36. We described radiologic parameters around the hindfoot and ankle joint including talar tilt, tibial-ankle surface angle, medial clear space, frontal tibial ground angle, frontal talar gound angle, hindfoot alignment view angle and measured the amount of change of knee alignment by comparing preoperative and postoperative X-rays. We divided cases into 4 groups, two with increased ankle pain postoperatively in previous ankle pain group and newly developed pain postoperatively. Pain was aggrevated compared preoperatively was other subgroup, and the other had no change. We compared 4 groups in each parameter and analyzed statistically (SPSS v13.0).

\section{Results}

There was change of ankle pain in 15 cases of 71 patients (80 cases) with over 6 months of follow-up period. Twelve patients had ankle pain before surgery. In

\footnotetext{
Correspondence: ortho1@hanmail.net

Department of Orthopedic Surgery, Busan Paik Hospital, College of Medicine, Inje University, 633-165 Gaegeum-dong, Busan Jin-gu, Busan 614-735, South
} Korea

(C) 2014 Gwak; licensee BioMed Central Ltd. This is an Open Access article distributed under the terms of the Creative Commons Attribution License (http://creativecommons.org/licenses/by/4.0), which permits unrestricted use, distribution, and reproduction in any medium, provided the original work is properly cited. The Creative Commons Public Domain Dedication waiver (http:// creativecommons.org/publicdomain/zero/1.0/) applies to the data made available in this article, unless otherwise stated. and take full advantage of:

- Convenient online submission

- Thorough peer review

- No space constraints or color figure charges

- Immediate publication on acceptance

- Inclusion in PubMed, CAS, Scopus and Google Scholar

- Research which is freely available for redistribution

Submit your manuscript at Submit your manuscript at C BioMed Central 